\title{
Differential Tolerance of Sugarcane Cultivars to Clomazone
}

BARCELLOS JÚNIOR, L.H. ${ }^{*}$ * PEREIRA, G.A.M. ${ }^{1}$

GONÇALVES, V.A. ${ }^{1}$

MATOS, C.C. ${ }^{1}$

SILVA, A.A. ${ }^{1}$

\section{* Corresponding author:}

<lucasheringerbj@hotmail.com>

Received: September 16, 2016

Approved: September 21, 2016

Planta Daninha 2017; v35:e17169352

\section{Tolerância Diferencial de Cultivares de Cana-de-Açúcar ao Clomazone}

ABSTRACT - Weed control is one of the most relevant costs of sugarcane production. If weeds are not controlled at the right time, the productivity and longevity of sugarcane plantations are reduced. In this crop, chemical control is the most used method, since it is efficient and it has a lower cost. Differentiated tolerance of sugarcane cultivars to the herbicide clomazone has been observed in the fields. However, there is no scientific evidence of this effect on the productivity of crops. This study evaluated the effects of clomazone on three sugarcane cultivars (RB966928, RB93579 and RB867515). Herbicide application was performed 40 days after the emergence of sugarcane plants and 7, 14, 21 and 28 days after the application, the toxicity caused by the herbicide in the culture was evaluated through grades ranging from 0 (no toxicity) to 100 (plant death). The harvest was performed 580 days after the herbicide application. On this occasion, the length and diameter of the stem, number of tillers, tons of stems per hectare, total soluble solids of the juice, sucrose of the juice, apparent purity of the juice, sugarcane fiber, reducing sugars and total recoverable sugars were evaluated. The differential tolerance among sugarcane cultivars in response to clomazone application in the early stages of crop development was confirmed. Nevertheless, in all cultivars, the symptoms of intoxication disappeared over time and did not reflect on crop productivity. It was concluded that plant control in the sugarcane crop with clomazone, following the recommendation of the manufacturer, does not interfere negatively in the growth, development and productivity of the crop.

Keywords: selectivity, Saccharum spp., herbicide.

RESUMO - As plantas daninhas, se não controladas no momento adequado, reduzem a produtividade e longevidade dos canaviais. Nesta cultura, o método químico de controle das plantas daninhas, por ser eficiente e de menor custo, éo mais utilizado. No campo, tem-se observado tolerância diferenciada de cultivares de cana-de-açúcar ao herbicida clomazone. Contudo, não existe comprovação cientifica desse efeito sobre a produtividade dos cultivares. Neste trabalho foram avaliados os efeitos do clomazone em três cultivares de cana-de-açúcar (RB966928, RB93579 e RB867515). A aplicação do herbicida foi feita aos 40 dias após emergência das plantas de cana, e aos 7, 14, 21 e 28 dias após a aplicação foram avaliadas as intoxicações causadas pelo herbicida na cultura, atribuindo-se notas que variaram de 0 (ausência de intoxicação) até 100 (morte das plantas). Aos 580 dias após a aplicação foi realizada a colheita da cultura. Nessa ocasião, foram avaliados o comprimento e diâmetro do colmo, número de perfilho, tonelada de colmos por hectare, sólidos solúveis totais do caldo, sacarose do caldo, pureza aparente do caldo, fibra da cana, açúcares redutores e açúcares totais recuperáveis. Foi confirmada a tolerância diferenciada entre cultivares de cana-de-açúcar à aplicação do clomazone no início de desenvolvimento da cultura. Entretanto, os

1 Universidade Federal de Viçosa, Viçosa-MG, Brazil. 
sintomas de intoxicação desapareceram ao longo do tempo e não refletiram na produtividade da cultura. Concluiu-se que o controle de plantas na cultura da cana-de-açúcar com o clomazone, seguindo a recomendação do fabricante, não interfere no crescimento, no desenvolvimento e na produtividade da cultura.

Palavras-chave: seletividade, Saccharum spp., herbicida.

\section{INTRODUCTION}

Sugarcane (Saccharum spp.) is of great importance in the Brazilian agribusiness. Currently in Brazil, more than 8 million hectares of this crop are cultivated, which is a raw material for sugar and alcohol production; in addition, it is used as fodder (Conab, 2016). Among the components of sugarcane production costs are weed control expenses (Johanns and Contiero, 2006), which, if not controlled at the right time, reduce the productivity and longevity of sugarcane plantations (Kuva et al., 2003).

Some studies (Kuva et al., 2003; Carvalho et al., 2010) report that the productivity of sugarcane is directly influenced, among other factors, by the presence of weeds. In addition to making it difficult to cut and harvest, weeds cause the decrease of industrial income, resulting in losses of up to $80 \%$ (Azania et al., 2008). Because they are cultivated in extensive areas, the chemical method of weed control is the most used. The choice of this method is also justified by its high efficiency and lower cost when compared to other methods, and by the availability of this technology in the country's producing regions (Christoffoleti et al., 2006).

Usually, when registering a herbicide for a crop, it is established as a rule that all cultivars of that species should be selective to the product. Nonetheless, despite anatomical, morphological and physiological similarities among cultivars of cultivated species, there is a risk of intoxication of new genetic material (cultivars) by herbicides already registered for the species. Although there are several studies reporting the differential tolerance of genotypes to the most diverse herbicides, specifically for sugarcane, it is not common standard to confer tolerance of new cultivars launched on the market. Therefore, studies in this area are scarce, being highlighted the researches by Azania et al. (2006) and Barela and Christoffoleti (2006).

Among the various herbicides registered in Brazil, the clomazone stands out. It belongs to the chemical group of isoxazolidinones, being widely used in Brazil in the control of mono- and eudicotyledonous weeds, in crops such as sugarcane, cotton, rice, potato, tobacco and cassava (Anvisa, 2016).

Although clomazone is recommended for use in sugarcane crops, the cultivars have a differential tolerance to this herbicide. However, the results of the available research do not conclude whether the intoxication of the plants caused by this herbicide, shortly after its application, results in a reduction in the productivity of the sugarcane plantation, with losses to the producer. In view of the above, this study aimed to confirm the hypothesis that there is a differential tolerance of sugarcane cultivars to clomazone and that this may result in a reduction in the productivity of cultivars of greater sensitivity to the herbicide.

\section{MATERIAL AND METHODS}

The experiment was carried out in Viçosa, MG (latitude: 20 45'14" S and longitude: 42 ${ }^{\circ} 52^{\prime} 55^{\prime \prime}$ W) between February 2014 and September 2015, aiming at the production of one-anda-half-year sugarcane. The factorial scheme $3 \times 5$ was adopted. Factor A was composed of three cultivars of sugarcane (RB 966928, RB 93579 and RB 867515), and factor B, of five doses: 0; 0.375; $0.75 ; 1.125$; and $1.5 \mathrm{~g} \mathrm{ha}^{-1}$, relative to $0 ; 0.5 ; 1 ; 1.5$; and 2 times the dose of the active ingredient (clomazone). In the selection of cultivars to be evaluated, information provided by producers was considered. They observed that, among the most cultivated materials in the region, the cultivar RB 867515 is more tolerant to clomazone, and the RB 93579, the most sensitive. The treatments were arranged in a randomized block design with four replications. The experimental units 
were composed of boxes containing 150 liters of samples of a Red-Yellow Latosol. The results of the chemical and physical analyzes of the used soil samples are presented in Table 1.

The sugarcane sowing occurred in furrows made in the soil contained within the 150L box, $0.15 \mathrm{~m}$ deep, putting an average of 10 buds per meter of furrow (diameter of the box). The materials for sowing came from the CECA (Sugarcane Research and Breeding Center). The substrate suitability regarding the nutrition was made by sowing and coverage fertilization, according to the recommendations for the crop (CFSEMG, 1999), the latter being performed 60 days after the emergence. Irrigations were performed by drip system, respecting the crop needs, complementing the precipitations during the experimental period (Figure 1).

Table 1 - Results of the chemical and physical analyzes of the Red-Yellow Latosol, used in the experiment

\begin{tabular}{|c|c|c|c|c|c|c|c|c|c|c|}
\hline \multirow{2}{*}{$\frac{\mathrm{pH}}{\left(\mathrm{H}_{2} \mathrm{O}\right)}$} & $\mathrm{P}$ & $\mathrm{K}$ & $\mathrm{Ca}^{2+}$ & $\mathrm{Mg}^{2+}$ & $\mathrm{Al}^{3+}$ & $\mathrm{H}+\mathrm{Al}$ & $(\mathrm{t})$ & $\mathrm{V}$ & $\mathrm{m}$ & $\mathrm{OM}$ \\
\hline & \multicolumn{2}{|c|}{$\left(\mathrm{mg} \mathrm{dm}^{-3}\right)$} & \multicolumn{5}{|c|}{$\left(\mathrm{cmol}_{\mathrm{c}} \mathrm{dm}^{-3}\right)$} & \multicolumn{3}{|c|}{$(\%)$} \\
\hline 6.0 & 0.6 & 9 & 0.34 & 0.15 & 0.0 & 2.52 & 0.79 & 60.0 & 0.0 & 2.07 \\
\hline \multicolumn{3}{|c|}{ Coarse Sand } & Fine Sand & Sil & & Clay & & \multirow{2}{*}{\multicolumn{3}{|c|}{ Textural Class }} \\
\hline \multicolumn{7}{|c|}{$\left.\left(\text { dag }^{-1}\right)^{-1}\right)$} & & & & \\
\hline & 1 & & 10 & 17 & & 62 & & \multicolumn{3}{|c|}{ Very Argillaceous } \\
\hline
\end{tabular}

Analyzes carried out in the Soil Analysis Laboratory of Viçosa, according to the methodology of the Brazilian Agricultural Research Corporation - Embrapa (1997); $(\mathrm{t})=$ effective cation exchange capacity; $\mathrm{V}=$ base saturation; $\mathrm{m}=$ Saturation by $\mathrm{Al}^{+3}$; $\mathrm{OM}=$ organic matter.

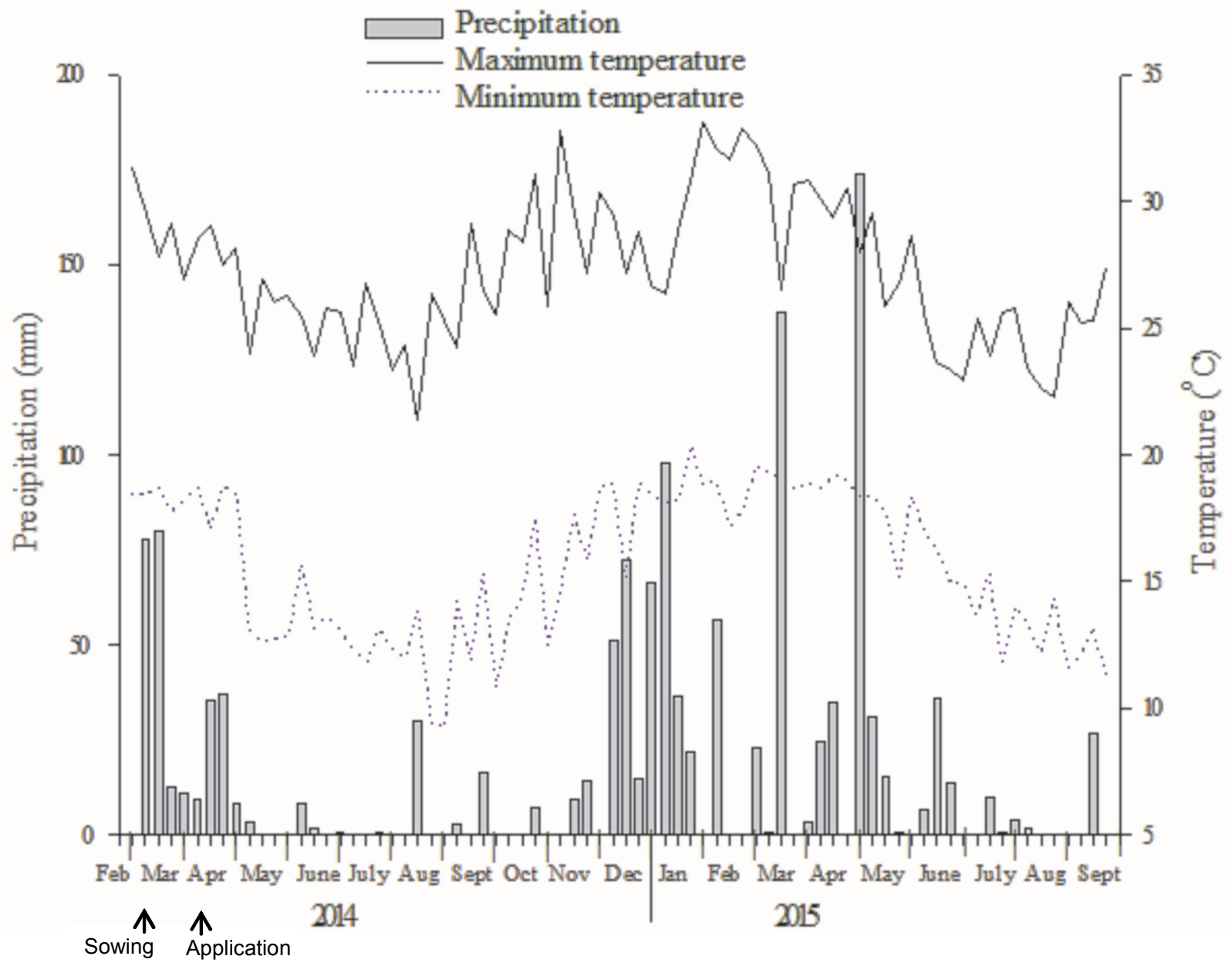

Figure 1 - Rainfall $(\mathrm{mm})$ and maximum and minimum weekly temperatures $\left({ }^{\circ} \mathrm{C}\right)$ in the experimental area during the period of the conduction of the experiment. 
The application of the herbicide was performed 40 days after the emergence of the plants (Figure 1), using a precision dorsal sprayer, applying the different doses of clomazone $(0.375$, $0.75,1.125$ and $1.5 \mathrm{~g} \mathrm{ha}^{-1}$ ), with a spray volume equivalent to $150 \mathrm{~L} \mathrm{ha}^{-1}$. Gamit ${ }^{\circledR}$ was used as the commercial product of clomazone.

Seven, 14, 21 and 28 days after the application of the herbicide (DAA), the intoxications caused in the sugarcane plants were evaluated, assigning them grades ranging from 0 (absence of intoxication) to 100 (plant death), according to the modified EWRC scale (1964). Five hundred and eighty days after the emergence, using the methodology described by Gheller et al. (1999), the stem length $(\mathrm{m})$, stem diameter $(\mathrm{mm})$ and number of tiller $\left(\mathrm{m}^{-1}\right)$ were evaluated. To estimate the crop productivity, the mathematical model proposed by Martins and Landell (1995) was used:

$$
T S H=D^{2} \times C \times H \times\left(\frac{0,007854}{F}\right)
$$

in which TSH $=$ tons of sugarcane per hectare $\left(\mathrm{t} \mathrm{ha}^{-1}\right) ; \mathrm{D}=$ stem diameter $(\mathrm{mm}) ; \mathrm{C}=$ number of tiller $\left(\mathrm{m}^{-1}\right) ; \mathrm{H}=$ average length of stems $(\mathrm{m}) ; \mathrm{E}=$ furrow spacing $(\mathrm{m})$.

The technological analyzes were carried out at the Sugarcane Research and Breeding Center, in the municipality of Oratórios, MG. Five random whole stems were collected in each plot and then the de-topping at the height of the apical bud and the defoliation were performed, as described in the Consecana's (2006) instruction manual of quality analysis of sugarcane, sugar and alcohol. The following data were obtained: total soluble solids ( ${ }^{\circ}$ Brix) of the juice, sucrose (pol\%) of the juice, apparent purity of the juice (\%), sugarcane fiber (\%), reducing sugars (RS\%) and total recoverable sugars, (TRS, $\mathrm{kg} \mathrm{t}^{-1}$ ).

Data on the percentage of intoxication were descriptively analyzed using the confidence interval at a 5\% probability level. The agronomic and technological data were submitted to analysis of variance and, when significant, were compared by the Tukey test at a $5 \%$ error probability.

\section{RESULTS AND DISCUSSION}

The symptoms of clomazone intoxication in sugarcane plants were evident in all evaluated doses and cultivars. They were characterized by the whitening of the young tissues and subsequent necrosis, and, in some cases, the death of the leaves occurred (Figure 2). These symptoms are typical of herbicides that act on carotenoid biosynthesis, reducing the ability of these pigments to dissipate the excess energy in the aerial part of the plants (Odero et al., 2015). This excess of energy not dissipated by carotenoids promotes oxidative effects on the chlorophyll and on the photosynthetic membranes, resulting in characteristic symptoms (Figure 2) (Dan Hess, 2000).

In the evaluation carried out seven days after the application of the herbicide, a higher intensity of symptoms of clomazone intoxication in the cultivar RB 93579 was observed for the lower dose. At higher doses, the symptoms, in the evaluated cultivars, presented similar intensities, with values close to $50 \%$ (Figure 3A).

Similar results were also observed by Ferreira et al. (2012), which observed that the cultivar RB 925345 of sugarcane showed high sensitivity to clomazone, while the cultivar RB 867515 was more tolerant to this herbicide. In general, as the days went by after the application, the symptoms were alleviated even at higher doses. The cultivar RB 93579, which suffered the most damage, had a slower recovery even at the lowest dose (Figure 3A, B, C and D). These results corroborate the ones found by Ferreira et al. (2012), who observed that the cultivars showed high toxicity to clomazone, mainly between 7 and 21 days after the application of the treatments, recovering with the passage of days. Nevertheless, differently from this one, these studies did not evaluate the effects of the herbicide on the productivity of the one-and-a-half-year sugarcane plantation.

For the agronomic and technological variables (length, stem diameter, number of tillers, ${ }^{\circ}$ brix, pol\% of sugarcane, fiber and RS), an effect was observed only among cultivars (Figures 4 and 5), these differences thus being inherent to each genotype. Regarding the other 

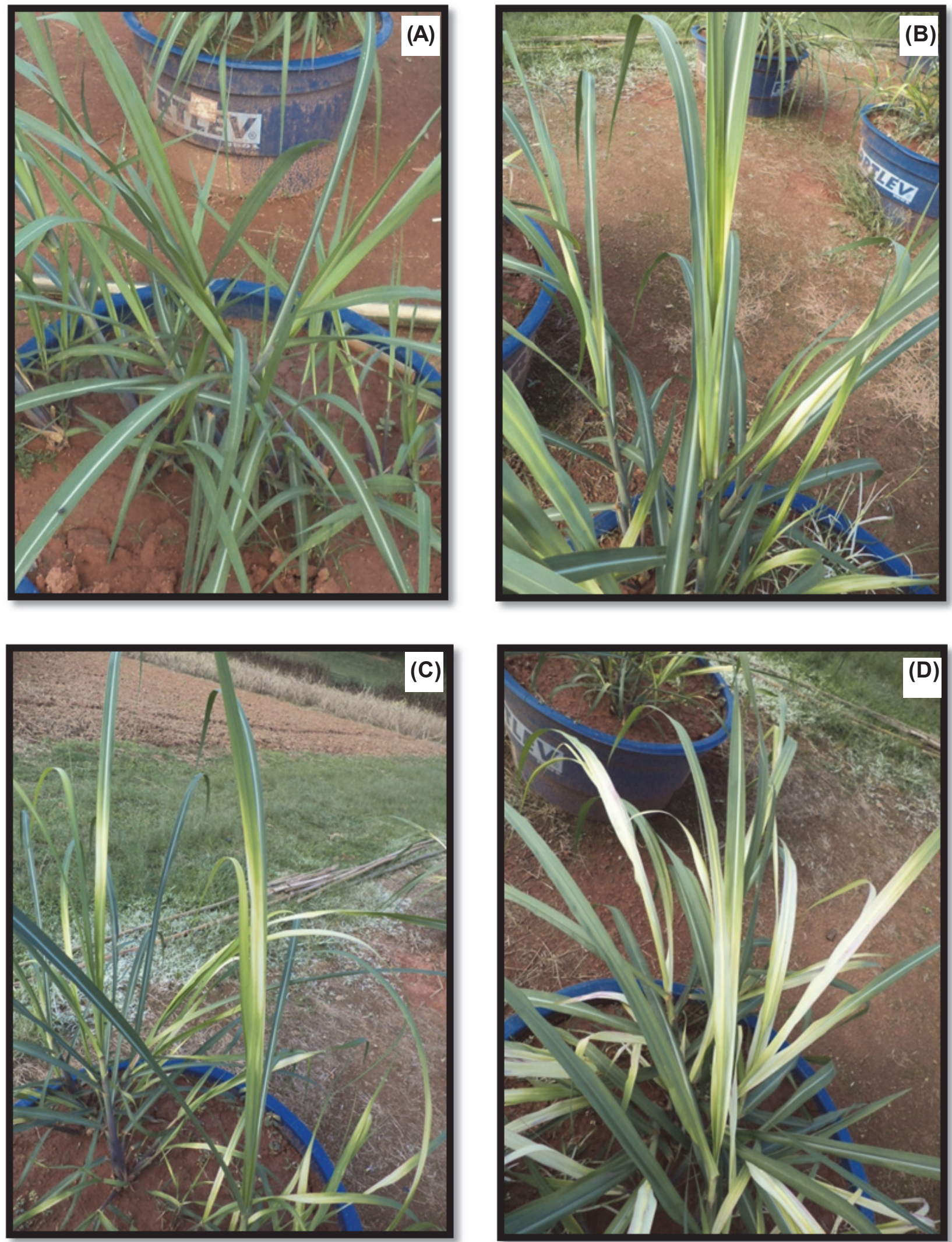

Figure 2 - Symptoms of intoxication of sugarcane plants by clomazone ( $0.75 \mathrm{~g} \mathrm{ha}^{-1}$ of clomazone $) 7$ days after the application: (A) control; (B) cultivar RB 867515, (C) cultivar RB 966928; (D) cultivar RB 93579. 

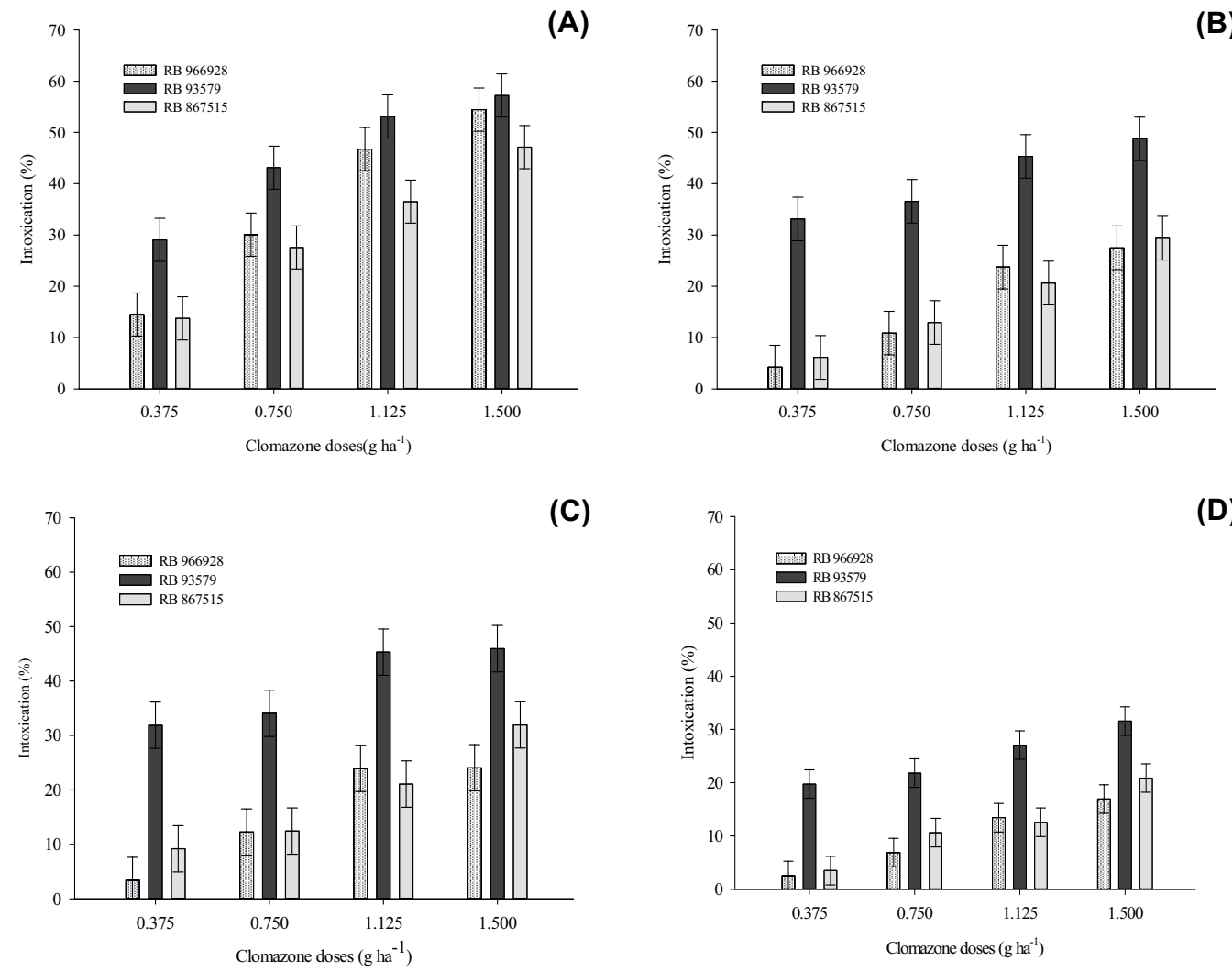

(D)

Figure 3 - Percentage of intoxication of sugarcane cultivars by clomazone in evaluations performed at 7 (A), 14 (B), 21 (C) and 28 DAA (D).

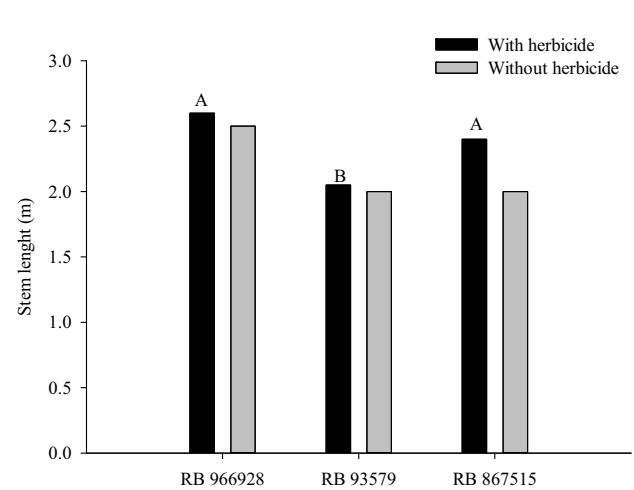

(A)

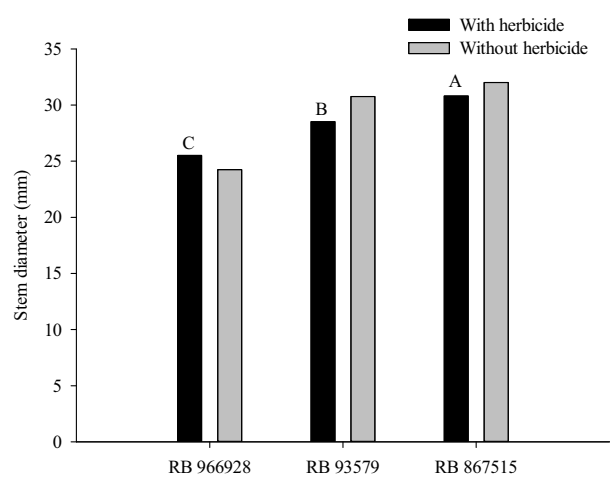

(B)

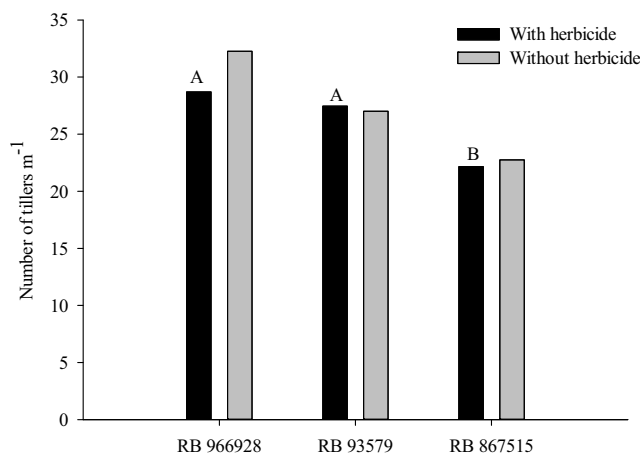

(C)

Averages followed by different letters statistically differ by the Tukey test at a $5 \%$ probability.

Figure 4 - Stem length (A), stem diameter (B) and number of tiller (C) of the cultivars RB 966928, RB 93579 and RB 867515 submitted to applications of clomazone. 

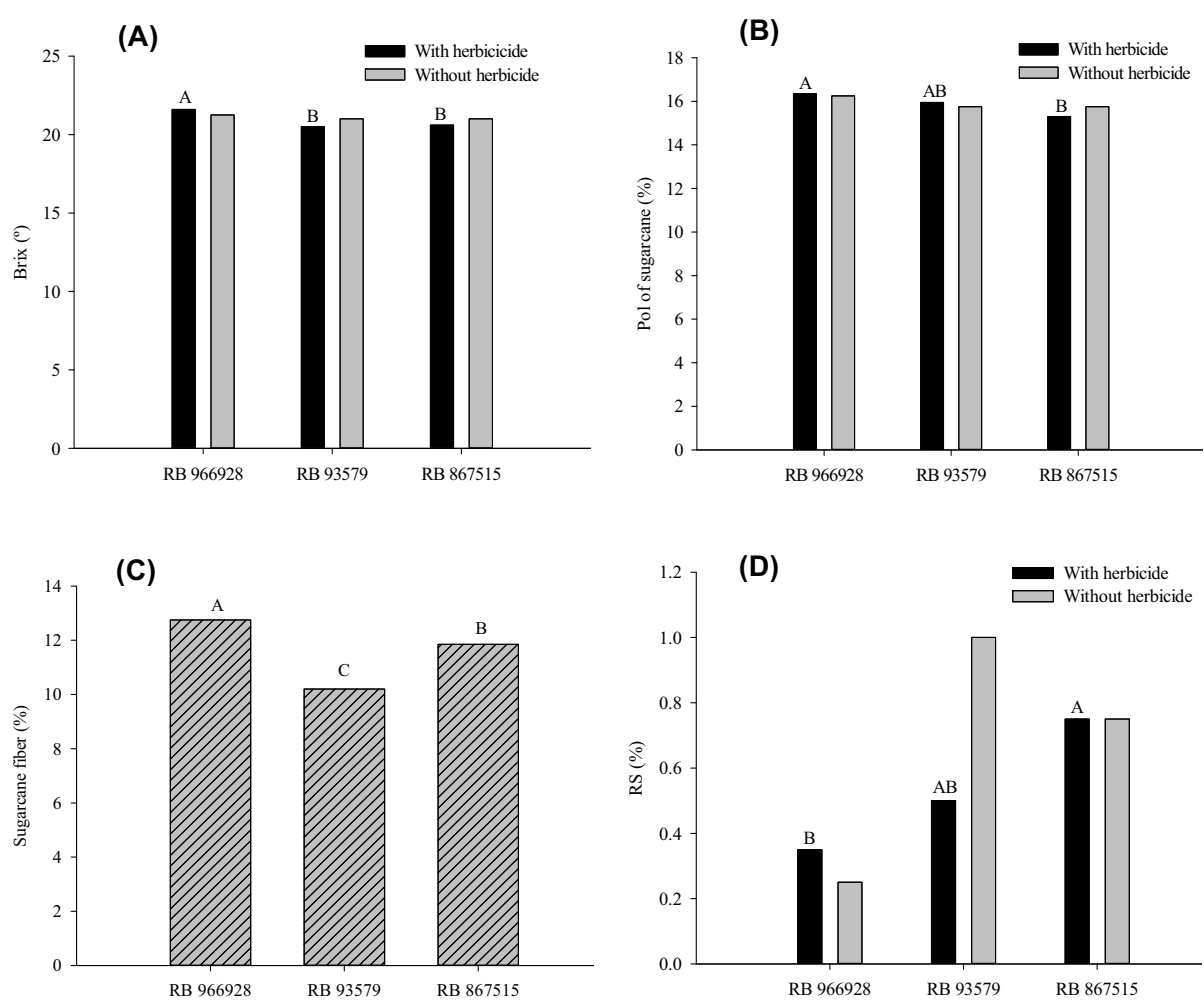

Averages followed by different letters statistically differ by the Tukey test at a $5 \%$ probability.

Figure 5 - Percentage of Brix $^{\circ}$ (A), pol of sugarcane (B), fiber (C) and reducing sugars (D) of the cultivars RB 966928 , RB 93579 and RB 867515 submitted to applications of clomazone.
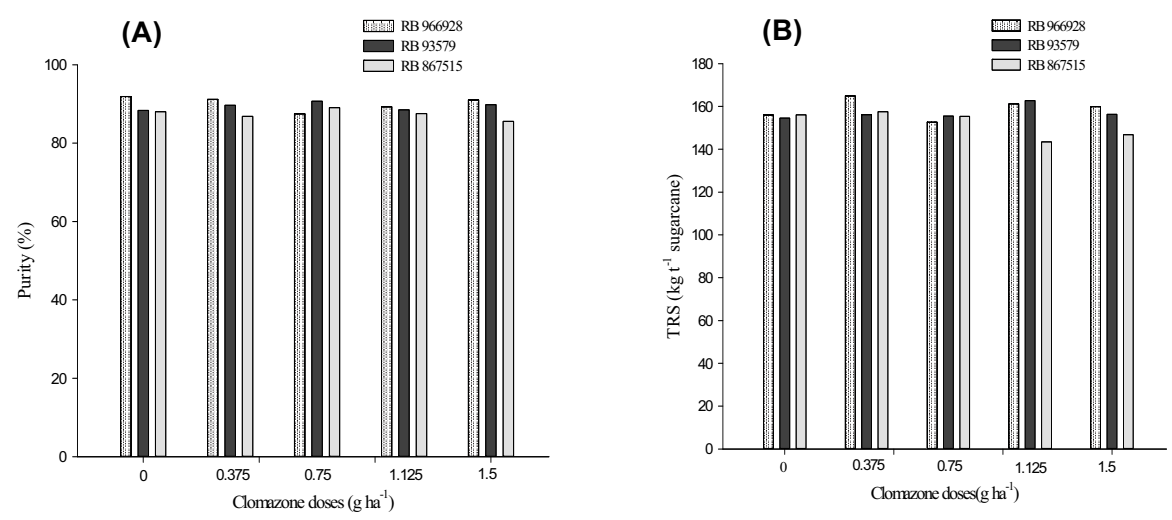

(C)

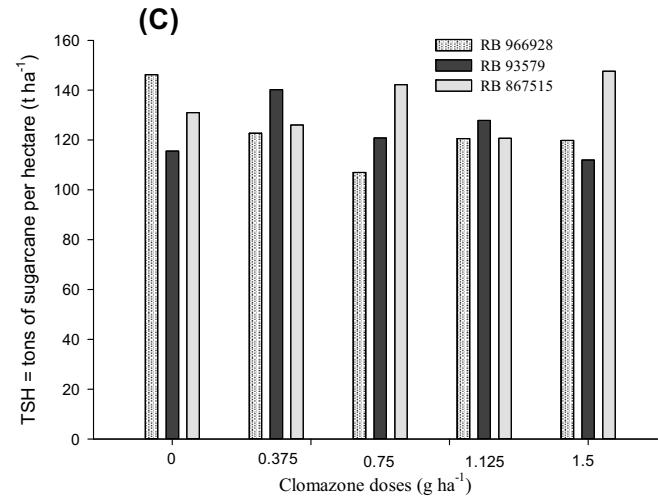

Figure 6 - Percentage of purity (A), total recoverable sugars (B) and tons of stems per hectare (C) for the cultivars RB 966928, RB 93579 and RB 867515 submitted to applications of clomazone. 
technological variables (purity and TRS) and productivity (TSH), there was no significant difference among the factors under study (Figure 6).

It was concluded that, although there is a differential tolerance among sugarcane cultivars to clomazone, these symptoms disappear with time, not reflecting on the productivity and quality of the harvested product.

\section{REFERENCES}

Agencia Nacional de Vigilância Sanitária - Anvisa. [accessed March 20 2016] Available: http://portal.anvisa.gov.br/wps/portal/ anvisa/home.

Azania C.A.M. et al. Seletividade de herbicidas. III - aplicação de herbicidas em pós-emergência inicial e tardia da cana-de-açúcar na época da estiagem. Planta Daninha. 2006;24:489-95.

Azania C.A.M., Rolim J.C., Azania A.A.P.M. Plantas daninhas. In: Dinardo-Miranda L.L., Vasconcelos A.C.M., Landell G.A. Cana-de-Açúcar. Campinas: Instituto Agronômico, 2008. p.465-90.

Barela J.F., Christoffoleti P.J. Seletividade de herbicidas aplicados em pré-emergência da cultura da cana-de-açúcar (RB 867515) tratada com nematicidas. Planta Daninha. 2006;24:371-78.

Carvalho F.T. et al. Controle de dez espécies daninhas em cana-de-açúcar com o herbicida mesotrione em mistura com ametryn e metribuzin. Planta Daninha. 2010;28:585-90.

Christoffoleti P.J. et al. Carfentrazone-ethyl aplicado em pós-emergência para o controle de Ipomoea spp. e Commelina benghalensis na cultura da cana-de-açúcar. Planta Daninha. 2006;24: 83-90.

Comissão de Fertilidade do Solo do Estado de Minas Gerais - CFSEMG. Recomendações para o uso de corretivos e fertilizantes em Minas Gerais. Lavras: 1999. 359p.

Companhia Nacional de Abastecimento - Conab. Acompanhamento da safra brasileira de cana-de-açúcar. Brasília, DF: Companhia Nacional de Abastecimento, 2016. 12p.

Conselho dos Produtores de Cana-de-Açúcar, Açúcar e Álcool do Estado de São Paulo - Consecana. Manual de Instruções. São Paulo: 2006. 112p.

Dan Hess F. Light-dependent herbicides: an overwiew. Weed Sci. 2000;48:160-70.

Empresa Brasileira de Pesquisa Agropecuária - Embrapa. Manual de métodos de análises de solo. Rio de Janeiro: 1997. 212p.

European Weed Research Council - EWRC. Cite of methods in weed research. Weed Res. 1964;4:88.

Ferreira E.A. et al. Toxidade de herbicidas a genótipos de cana-de-açúcar. Rev Trópica Ci Agr Biol. 2012;6:84-92.

Gheller A.C.A. et al. Manual de método alternativo para medição da produção de cana-de-açúcar. Araras: $1999.7 \mathrm{p}$.

Johanns O., Contiero R.B. Efeitos de diferentes períodos de controle e convivência de plantas daninhas com a cultura da mandioca. Rev Ci Agron. 2006;37:326-31.

Kuva M.A. et al. Períodos de interferência das plantas daninhas na cultura da cana-de-açúcar. III - Capim-braquiária (Brachiaria decumbens) e capim-colonião (Panicum maximum). Planta Daninha. 2003;21:37-44.

Martins A.L.M., Landell M.G.A. Conceitos e critérios para avaliação experimental em cana-de-açúcar utilizados no programa Cana IAC. Pindorama: Instituto Agronômico, 1995. p.2-14.

Odero D.C. et al. Response of energycane to preemergence and postemergence herbicides. Weed Technol. 2015;29:810-20. 